\title{
i[글
}

\section{The Role of Diaspora in the Promotion of the Albanian Economy}

\author{
Ph.D. c. Florenca Gjorduni \\ University of Bari "Aldo Moro" \\ Department of Economics and Finance in Public Administration
}

\begin{abstract}
:
The immediate opening of the country to the world, accompanied by a deep political, economic and social crisis were the main factors that stimulated the first flows of international migration in Albania after the fall of communism. Initially the emigration and the remittances were a solution to the chaotic situation in which the country found itself. But after a few years the immigration phenomenon is considered as a negative phenomenon. It was evaluated negatively because those leaving were young people of working age, qualified people and the demographic composition of a country is an element that affects economic development.

Today, the countries are thinking about how to take advantage of this inevitable reality brought about by free movement and globalization.Investors of the diaspora are particularly important for developing countrys such as Albania, where foreign investors refuse to invest due to inadequate economic structure, political instability, inadequate infrastructure, etc. Diaspora investors invest because in addition to the profit motive they are inspired by social and emotional factors to invest in their home country. Diaspora investments may also be less vulnerable to capital flight in a time of crisis. For more the diaspora investors play a crucial role in overcoming the isolation of poor countries from the flows of global trade. The purpose of this analysis is to study the contribution of the Albanian diaspora to the development of the economy. Analyzing the role of the diaspora, their involvement in national issues, policies and mechanisms undertaken by the Albanian government for their withdrawal we can evaluate that the Albanian diaspora represents a great opportunity, still little exploited.
\end{abstract}

Keywords: diaspora, capital, global trade. 